\title{
Lembranças do pós-guerra no sul de Angola: vivências e reconstrução da vida cotidiana
}

DoI

http://dx.doi.org/10.11606/ 2179-0892.ra.2017.141652

\author{
Camila A. M. Sampaio \\ - Universidade Federal do Maranhão / São Luís, MA, Brasil \\ v. camsampaio@gmail.com
}

\section{RESUMO}

Neste artigo enfatizo a presença da guerra como evento crítico na trajetória de alguns habitantes da província do Cunene, ao sul de Angola. Percorro aspectos históricos gerais da região, mapeando o contexto de episódios de violência que marcaram o território. Apresento como o próprio Estado elege um heterodoxo monumento como símbolo da destruição gerada pela guerra, forjando para si uma imagem de Estado em prol da paz. São analisadas trajetórias e percepções de pessoas que vivenciaram a guerra em diferentes intensidades e reelaboram cotidianamente formas de estar no mundo. Ter visto "uma guerra só"; estar "à espera do marido"; receber a ajuda financeira e afetiva de uma "amizade interessada"; trabalhar de forma itinerante e nem sempre remunerada: todas essas são formas que ultrapassam o lugar do trauma e que se adaptam diariamente às possibilidades diante daquele contexto. 
O ano de 2012 foi o marco da primeira década sem guerras em Angola após aproximadamente 40 anos de conflitos, entre guerras pela Independência, conquistada em 1975, e posteriores confrontos entre diferentes frentes político-militares.

Além da destruição da infraestrutura urbana de diferentes cidades, de uma economia cujas prioridades focaram-se em torno das guerras e do enriquecimento de uns poucos, houve mortes e deslocamentos populacionais em grandes proporções. Sem a existência de quantitativo fundamentado em dados populacionais gerais e oficiais, censos parciais e agências humanitárias estimam que 1 milhão de pessoas tenham morrido e outros 4 milhões tenham sido deslocados de suas regiões de origem para outras, dentro ou fora do país (Hodges, 2002: 41).

A efeméride pelos tempos de "paz" é muito mais do que um marco macropolítico ou histórico. Faz parte dos discursos oficiais a ênfase nessa nova etapa que o país atravessa, iniciada em 2002, na qual a "paz" caminha como condição para a "reconstrução nacional", formando um contraponto possível às marcas deixadas pelos conflitos e suas consequências.

A capital, Luanda, embora tenha sido menos diretamente afetada por conflitos armados, conviveu com o "fantasma da guerra", tão bem retratado em romances literários de Ondjaki (2001; 2012), nos quais os personagens citadinos transitam entre lendas, memórias e experiências relacionadas ao cotidiano de um estado de guerra. Relatos sobre as experiências vividas na capital apontam para recrutamentos forçados aos exércitos em confronto, emigrações, arranjos para incrementar a renda e os meios de vida.

Neste artigo, enfatizo a presença da guerra como evento crítico na trajetória de alguns interlocutores que habitavam a província do Cunene, ao sul de Angola, durante os períodos em que realizei pesquisa de campo, entre 2010 e 2011 . A recomposição das histórias foi realizada a partir de diários de campo e do material de três entrevistas gravadas, cada caso indicado no texto.

A noção de evento crítico trabalhada por Veena Das $(1995 ; 2007)$ refere-se aos impactos que determinadas ocorrências sociais de grande vulto podem ocasionar em trajetórias individuais ao longo do tempo. A análise da autora sobre como as pessoas, em suas vidas cotidianas, são capazes de retomar um universo devastado por irrupções violentas que permanecem no tempo torna-se apurada a partir de etnografias que revelam como eventos críticos são incorporados na forma de estabelecer relações sociais.

Mesmo em casos cujas experiências de guerra não estivessem diretamente presentes, as consequências do conflito são referenciadas e sentidas no dia a dia daqueles cujos corpos e subjetividades têm em si "lembranças sempre a sangrar".

Na primeira parte do artigo, percorro aspectos históricos gerais da região do Cunene, mapeando o contexto de episódios de violência que marcaram o território. A seguir, apresento como o próprio Estado elege um heterodoxo monumento 
como símbolo da destruição gerada pela guerra, forjando para si uma imagem de Estado em prol da paz e da "reconstrução nacional". Nas seções seguintes, apresento trajetórias e percepções de pessoas que vivencia(ra)m a guerra em diferentes intensidades e reelaboram cotidianamente formas de estar no mundo. Em nenhum caso, os arranjos encontrados por essas pessoas são reverberações do que o discurso oficial destaca como propósito para a "reconstrução nacional".

\section{CUNENE: UM TERRITÓRIO ESTRATÉGICO PARA AS GUERRAS}

A região que atualmente engloba a província do Cunene foi um dos últimos territórios do continente africano invadido por europeus. No início do século XX, houve litígio, geralmente ocasionado pelo controle da água na região, pelo domínio da área entre Portugal, Alemanha e União Sul-Africana, que gerou resistências e deslocamentos das populações de origem étnico-linguística kwanyama. Esses povos formavam, até o período da invasão europeia, entre os atuais territórios de Angola e Namíbia, o Reino Oukwanyama (Vigne, 1998).

A Namíbia, então Sudoeste Africano, havia sido colônia alemã entre $1884 \mathrm{e}$ 1919. A colônia foi colocada em segundo plano durante a Primeira Cuerra Mundial (1914-1918), o que possibilitou, em 1915, a ocupação do território pela União Sul-Africana. Com a derrota da Alemanha na Primeira Guerra Mundial, os territórios que estavam sob seu domínio foram redistribuídos pela Liga das Nações. Assim, o Sudoeste Africano passou ser administrado pela União Sul-Africana em 1919.

A União Sul-Africana (1910-1961) obteve estatuto de domínio do Império Britânico no território da atual África do Sul, após a derrota dos bôeres, descendentes de europeus instalados na região desde os séculos XVII/XVIII. A União Sul-Africana reuniu sob o comando britânico áreas comandadas pelos bôeres e áreas que já estavam sob domínio britânico. Foi neste período que se instaurou oficialmente o regime do apartheid, em 1948. Em 1961 houve a desvinculação do Império Britânico e a adoção da designação de República da África do Sul, que continuou a ocupar ilegalmente o território do Sudoeste Africano e manteve o regime de segregação racial até a década de 1990.

No bojo dos movimentos independentistas dos países africanos, formou-se, no Sudoeste Africano, um movimento pela independência denominado Organização dos Povos do Sudoeste Africano (South West Africa People's Organization-SWAPO). A SWAPO constituiu-se como bloco hegemônico que deu início a uma guerra contra as forças armadas sul-africanas (South African Defense Force-SADF) em 1966 e se estendeu até 1990. Assim, a região não foi atingida apenas pelas guerras internas em Angola, mas também pela guerra de independência da Namíbia (1966-1989).

O governo no poder em Angola, desde 1975 até hoje, regido pelo Movimento Popular de Libertação de Angola, o MPLA, apoiava a SWAPO, inclusive no 
fornecimento de espaços em Angola para abrigar campos de treinamento. Os dois movimentos eram aliados desde antes da chegada do MPLA ao poder governamental, durante as guerras de libertação, nos anos 1960 (Willians, 2009). Entretanto, a região do Cunene, como outras áreas do sul e sudeste de Angola, foi ocupada também pela UNITA (União Nacional para a Independência Total de Angola). A UNITA formou-se em 1966, a partir de uma dissidência da Frente Nacional de Libertação de Angola (FNLA). Assim como o MPLA, foram movimentos pela libertação do país contra o regime colonial. Após a Independência, a UNITA tornou-se a principal força de oposição armada ao MPLA. Em diferentes momentos, a UNITA manteve alianças com as SAFD e manteve presença significativa na região sul e sudoeste de Angola, principalmente em áreas rurais.

Situada ao longo da fronteira, as províncias do Cuando-Cubango e do Cunene tornaram-se estratégicas para todas as forças relacionadas ao processo de Independência da Namíbia, pela suscetibilidade de confrontos entre MPLA e UNITA e ainda entre SWAPO e SADF. O exército oficial sul-africano adentrava o território angolano, por vezes com suporte declarado da UNITA, sob o argumento de estar à procura de rebeldes da guerra pela independência da Namíbia.

A SADF, com apoio da UNITA, invadiu o Cunene logo após a Independência de Angola, ao fim de 1975, em busca de desestabilizar o regime recém-independente proclamado pelo MPLA. Angola independente com uma orientação socialista e aliada a SWAPO iria contra os interesses sul-africanos. Como resposta, o MPLA, com apoio da União Soviética, trouxe tropas cubanas e militares do governo para ocupar as cidades. A segunda invasão da SADF foi em 1981, quando o edifício de governo, ocupado por tropas cubanas e do MPLA, foi bombardeado, reduzindo-se a escombros que posteriormente foram transformados em monumento. As guerrilhas pela Independência da Namíbia se desenrolaram no sul de Angola até 1988, quando se realizaram os Acordos de Nova York para a retirada das forças armadas cubanas e fim das invasões e intervenções da SADF em Angola. De forma paralela, os Acordos previram intervenção das Nações Unidas na área, concluída em 1990, com o reconhecimento oficial da Independência da Namíbia e a retirada das tropas das cidades (Domingos, 2013).

Em 1991, o Acordo de Bicesse (ou Acordo de Estoril), entre MPLA e UNITA, mediado por Portugal e observado pelos EUA e URSS, selou a primeira tentativa de finalizar a guerra. No contexto mundial, vivia-se o fim da Guerra Fria e a subsequente dissolução da União Soviética. Entre os principais pontos do acordo, constavam o final da guerra civil, a abertura de um processo de democratização partidária, a realização de eleições com bases democráticas e a criação das Forças Armadas Angolanas, apartidárias e com a recomendação de receber antigos combatentes dos exércitos de guerra do MPLA e da UNITA (Domingos, 2013).

Em 1992, realizaram-se eleições em Angola. No Cunene, neste mesmo ano, 
a capital Ondjiva foi retomada pelo governo do MPLA (e não mais por tropas). A UNITA manteve bases em estradas e ao leste da província. Apesar do Acordo de Bicesse, as principais partes envolvidas seguiam desconfiadas e não se desarmaram. Levantaram-se suspeitas de fraudes eleitorais apesar da ONU declarar as eleições livres e justas e Jonas Savimbi, líder da UNITA, reiniciou novo período de guerra que se seguiu até 1994 .

Um novo acordo em 1994, o Protocolo de Lusaka, foi assinado entre MPLA e UNITA. Entretanto, a UNITA optou por cumprir alguns aspectos do Protocolo, mas utilizou-se da trégua para não perder outros territórios e reequipar sua força militar, renovando o arsenal de guerra. As eleições de 1997 e 1998 foram postergadas, o que foi visto por alguns como al go ilegítimo. Os conflitos foram reiniciados em 1998. A UNITA, sob a liderança de Savimbi e já sem apoio da África do Sul não tinha interesses em disputas apenas no campo político e, por outro lado, o MPLA se esforçava, com suporte e controle das mídias, em construir uma imagem democrática e de paz em oposição à beligerante UNITA. Com o fim do apartheid sul-africano, em 1994, e a eleição de Nelson Mandela, em 1995, o novo governo sul-africano representado pelo African National Congress (ANC), partido no poder, passou a apoiar o regime do MPLA, seu antigo aliado. A guerra teve seu fim com a morte de Savimbi pelo exército angolano, em fevereiro de 2002, e com a gradativa diminuição de suporte à UNITA, que deixou de ter qualquer apoio internacional. O Memorando de Luena, de 4 de abril de 2002, selou o fim da guerra.

Para muitos angolanos, a morte de Jonas Savimbi, líder da UNITA, pouco antes da assinatura do Memorando de Luena, foi um marco simbólico que representou o fim das guerras. No Cunene, a morte de Savimbi foi motivo de festejos que atravessaram os dias. Danilo, um rapaz nascido em meados da década de 1980 e que cresceu convivendo sob ameaças de ser raptado pela UNITA disse-me, enquanto conversávamos durante uma manhã em Ondjiva: "No dia que o Savimbi morreu, não houve um lugar sem festas. Mataram bois e cabritos, todos comemoraram. Não houve um só sítio sem festejo no Cunene".

O alívio de Danilo e os festejos na província indicaram o fim de uma sucessão de eventos críticos. Enquanto isso, a memória de muitos, não só como substrato, mas como memória corporificada, estava sendo constituída a partir de dores que Ihes foram infligidas.

\section{“RECONSTRUÇÃO NACIONAL" E ESCOMBROS COMO MONUMENTO}

O termo "reconstrução nacional" passou a ser mencionado frequentemente com o fim da guerra em 2002. Ainda em 2012, a ideia operava mais como um discurso propalado pelo governo pós-guerra de José Eduardo dos Santos que como um marco diferenciador de uma nova forma de se fazer política. Com a perspectiva 
da "reconstrução nacional" sempre presente em seus discursos, o presidente parecia construir para si a figura de um pacificador fundamental para o fim das guerras e para a formação de uma "Nova Angola". Subjacente a essa ideia estaria o objetivo de bem comum para todos, acionado como elemento discursivo em prol da ampliação de projetos que colocariam Angola como um país em desenvolvimento capaz de superar os anos de guerra.

O tema da propaganda governamental condensava algo delineado anteriormente, desde os anos 1990, com a abertura da economia ao capital estrangeiro, mediado pela elite local, em articulações que pouco interferiram na distribuição da riqueza produzida (Hodges, 2002). Com o fim das guerras, o movimento de expansão do capital e concentração de renda aumentou. Os recursos e investimentos destacaram-se na extração de petróleo e diamantes, no comércio de importação/exportação e na construção civil.

Em 2010, as zonas urbanas da província do Cunene representavam o retrato da "reconstrução nacional". Na capital, Ondjiva, havia obras visíveis em edifícios e nas ruas; em Santa Clara, posto fronteiriço com a Namíbia, a construção em andamento do que seria um porto seco estratégico na rota comercial Angola-Namíbia-África do Sul. Na sede do governo provincial, um grande retrato legendado do presidente angolano em outdoor indicava a unidade nacional pela presença personificada do Estado (Figura 1).

\section{Figura 1}

Sede do Governo Provincial do Cunene. Fonte: A autora, 2011

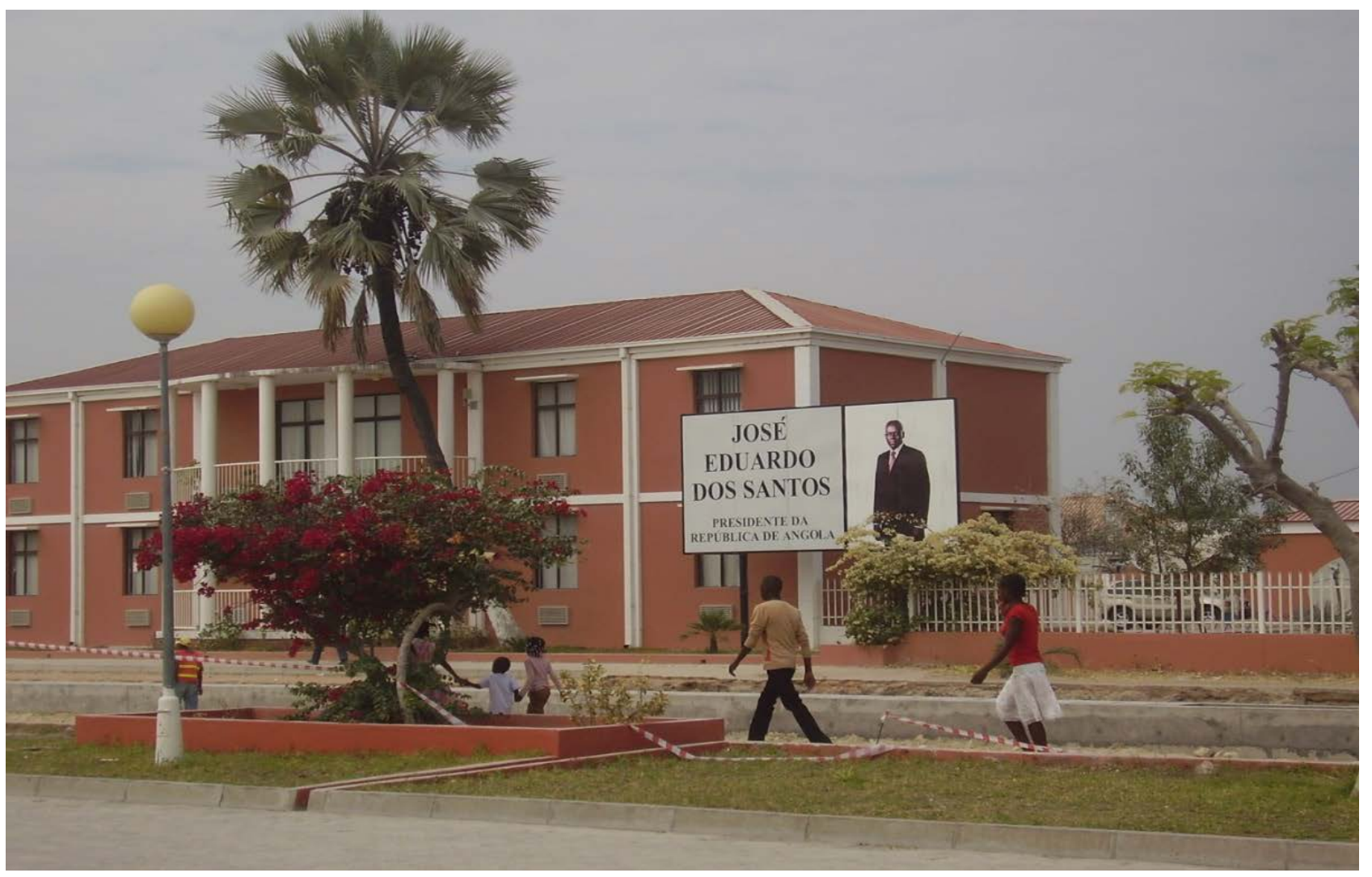


Sem guerras e diante de visíveis mudanças em aspectos da infraestrutura do país, o Estado, concentrado no MPLA e na figura de José Eduardo dos Santos, aliou-se a grandes investidores e conclamou para si o papel de promotor da reconstrução nacional. Nesse modelo, foram poucos os atores sociais que receberam condições para a recomposição da vida no pós-guerra (Sampaio, 2014). Se as obras indicariam uma "nova Angola", os "tempos de guerra" ainda se pronunciavam com destaque para a maioria, como apresentaremos a seguir.

A presença da guerra na vida dos habitantes do Cunene aparecia concretamente na praça central de Ondjiva, capital da província, em frente a uma Igreja Católica. Escombros cercados por uma mureta recém-construída e uma placa explicativa formavam um conjunto classificado pelo poder público como monumento (Figura 2). Tratavam-se de destroços da sede do governo provincial, construída em 1969, ainda no período colonial, e destruída em 1981 pelas forças armadas sul-africanas com provável aceite da UNITA. Os escombros foram transformados nesse inusitado monumento em 1998, seis anos depois da retomada da cidade pelo governo angolano e no mesmo ano em que estavam agendadas eleições antes da retomada do conflito. A placa apresenta dizeres sobre a "importância da manutenção da memória do povo angolano sobre os duros tempos de guerra". Mas haveria como esquecer?

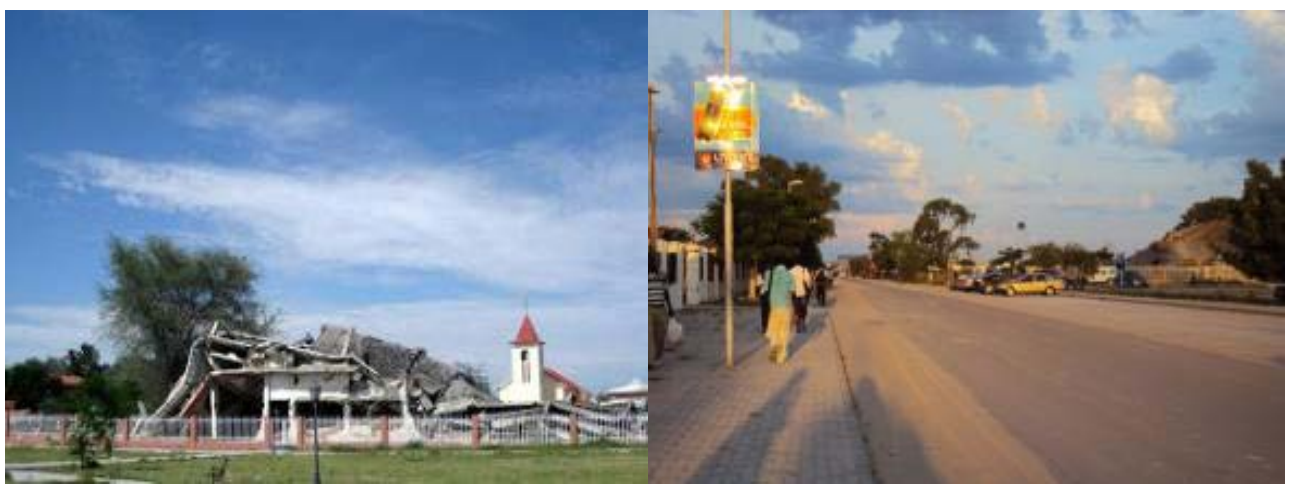

A transformação desses escombros em monumento no mesmo ano em que a guerra em Angola foi retomada, após um intervalo de quatro anos, pode ser considerada uma "emblemática representação dos ciclos de destruição e de resiliência" (Rodrigues, 2010: 468), que perpassam a região desde o início do século XX. O ato de inauguração, conduzido pelo próprio Presidente José Eduardo dos Santos, talvez tenha sido também uma sutil indicação para tornar visível e concreto quem seriam os "inimigos" que fizeram a guerra perdurar. Naquela etapa (1998-2002), a guerra em Angola concentrava-se na tentativa da UNITA em sobrepor-se ao MPLA na cúpula governamental.

A contribuição de Anderson (1998) para a compreensão da formação de

\section{Figura 2}

Monumento em Ondjiva localizado na praça central da cidade, em frente a um templo católico.

Fonte: Cooglemaps, 2011

\section{Figura 3}

Rua principal em Ondjiva. Fonte: A autora, 2011 
subjetividades dentro de fronteiras nacionais traz ao centro do debate a análise de lugares que carregariam "imagens nacionais espectrais", tais como túmulos, museus, monumentos e até mesmo a produção de dados por censos e levantamentos populacionais. Nesse sentido, assim como obras e propagandas indicam a "reconstrução nacional", a construção de uma mureta ao redor desses escombros apresenta-se como uma tentativa deliberada da frente política predominante para compor um entendimento específico do que construiu (e destruiu) a fronteira sul de Angola. Porém, a análise pode adquirir outras nuances a partir de elementos menos visíveis sobre os sentidos da guerra e outras formas de reconstrução e ressignificação da vida na região.

No mesmo dia que conheci Eneida, uma das principais interlocutoras que tive na província, soube que sempre vivera nos arredores. Quis saber mais detaIhes sobre o período de destruição daquele ex-edifício. Contei que li as inscrições da legenda sobre a manutenção da memória do povo angolano e lhe perguntei o que ela lembrava sobre essa época. Eneida foi rápida:

Estes, os sul-africanos do apartheid estavam a andar por aí, iam nos matos atrás da SWAPO, às vezes chegavam até a cidade. Mas a UNITA estava mesmo a ver que era bom, "Epá, assim as FLAPA [as tropas do governo], os cubanos, estão todos a ir!" teriam mais chances de dominar todo o Cunene. Pois bombardearam o edifício provincial, em um tempo em que tu não havias saído da poeira. Esse sítio aí, parado, com mosquitos... Seguir a "Reconstrução d'Angola" e construir um sítio bonito assim de ver, de passear estaria bom... E não isso, feio, de se tirar fora! O MPLA, os cubanos, a UNITA, os sul-africanos, todos afinal foram maus, muito maus nessa guerra. Os conflitos já não estão, mas já percebeste como a familia do Presidente tem dinheiro? Se quiseres recordar a guerra, não deves olhar o monumento. Deves olhar para o próprio povo, e o povo daqui, os kwanyama e os outros que cá estão... Em particular as mulheres... Já vais perceber como vivem as mulheres no Cunene!...

"Se quiseres recordar a guerra, deves olhar para o próprio povo, principalmente para as mulheres". As elaborações de Eneida e sua crítica implícita às descrições presentes no monumento carregavam uma grande densidade que, naquela hora, recém-chegada na região, não pude captar. Além da rápida explanação sobre disputas na macropolítica das últimas décadas, Eneida chamou a atenção para a centralidade das consequências que a guerra pode ter deixado na vida das pessoas, especialmente na vida das mulheres. Para ela, o monumento não trazia um significado tão impactante quanto as consequências não visíveis, talvez inomináveis, dos conflitos.

Aqui, no alerta de Eneida, encontro uma primeira proximidade a questões 
trazidas pela produção intelectual de Veena Das (1995; 2007). "Já vais perceber como vivem as mulheres no Cunene". Este "perceber" parecia um convite para buscar o outro sentido dos ol hos para que Veena Das nos chama a atenção: os olhos, além de ver, derramam lágrimas (Das, 2007: 61). E estas não são possíveis de captar apenas em dramáticos monumentos, ou em atos heroicos, rompantes. Os olhos que carregam as adversidades daqueles que sobrevivem cotidianamente após eventos críticos, tornam-se acessíveis em processos de reconhecimento da dor e do sofrimento que são incorporados ao ordinário da vida (Das, 2007).

$O$ insólito monumento que gera incômodo ao visitante passa a ter-e a ser-sentido ao adentrarmos a história e as experiências de quem ali viveu. De alguma forma, ele sintetiza um tipo de "gramática dos sobreviventes" da guerra. Nesta, mesmo que os conflitos tenham terminado, a guerra seria mais que um elemento presente e cotidiano: é constituinte na forma de perceber a si e aos outros e fundamental como maneira de viver no mundo.

As imagens da guerra e dos ciclos de destruição/reconstrução, bem como a perspectiva/necessidade de resiliência, operam como linguagem ordinária enquanto índices de eventos críticos. As diferentes intervenções, disputas e batalhas travadas na região são mencionadas, narradas, recontadas. Aparecem em um categórico monumento oficial, em carcaças de tanques de guerras encontradas nas estradas, em montinhos de armas descartadas em alguns cantos da cidade. Aparecem também em descompromissadas conversas, seja em referência a elementos concretos icônicos, como falar rotineiramente sobre "akás" (uso popular para um fuzil soviético amplamente utilizado nas guerras em Angola, o AK-47), "as tropas", os edifícios furados dos "tempos de guerra"; ou em falas mais abstratas e genéricas, como ações cruéis das tropas, o "corpo fechado" de Jonas Savimbi (a quem muitos se referem como um poderoso feiticeiro).

Das (1995) constrói uma perspectiva na qual ressalta a importância de trazer ao espaço público as articulações de experiências e sofrimentos geradas por eventos críticos, mas que são vivenciados de forma privada. A partir da análise de eventos críticos ocorridos em território indiano, a autora observa como discursos oficiais de Estado, em diferentes tempos e diante de situações críticas, utilizam-se de generalidades e eufemismos que uniformizam uma ideia de colapso social. Tais ações, observa Das (1995: 191), ignoram o ambiente de consentimento e cumplicidade que envolvem todo o contexto em que atrocidades são perpetradas. Criar vítimas e algozes sob discursos vazios de substância, sem o reconhecimento da dor como algo que deve ser coletivamente vivenciado, não cria subsídios para enfrentar as rupturas do tal "colapso".

Sob outro aspecto, as diretrizes gerais da "reconstrução nacional" pouco beneficiam as vidas de pessoas comuns, que não estão no centro da captação de recursos para as grandes obras e transações comerciais do boom econômico de Angola. 
Não existe eufemismo em um edifício bombardeado que o Estado transforma em monumento. Também não é exatamente um silêncio que se apresenta ao se pensar nas guerras. Mas entrevemos um arquétipo do modelo "vítimas" (o "povo angolano"? o MPLA?) versus "algozes" (as SADF? A UNITA?).

E aqui voltamos a Eneida e sua magistral observação feita no primeiro dia em que nos conhecemos: "Se quiseres recordar a guerra, não deves ol har o monumento. Deves olhar para (...) [os que] que cá estão". O que a reconstrução nacional guarda para essas pessoas?

\section{ZONA DE GUERRA E LUGARES SOCIAIS RAPTADOS}

Júlio e sua mãe, Heloísa, trabalhavam em um bar-pensão no povoado de Santa Clara, um importante posto fronteiriço entre Angola e Namíbia na época em que realizei pesquisa de campo, entre 2010 e 2011. Sem vínculos formais de trabalho, Júlio tinha alguma flexibilidade de "estar à toa" e uma profunda instabilidade econômica. Ele havia nascido em Angola, em um kimbo, que é um povoado rural, próximo à fronteira. Falava kwanyama, sua língua materna, inglês e africâner, pois vivera a maior parte da vida na Namíbia. Do português, apenas algumas expressões. Júlio acumulava experiência como "educador de pares" em programas de prevenção a doenças sexualmente transmissíveis na Namíbia e dominava a arte da conversa. Seu temperamento extrovertido lhe rendia contatos frequentes com os mais variados interlocutores. Em Santa Clara, estávamos sempre próximos, caminhando, conversando com outras mulheres ou debatendo algum tema sobre o contexto. Aos poucos, em conversas fragmentadas, fui compreendendo sua trajetória de vida. Um dia perguntei diretamente por que ele foi viver em Windhoek, capital da Namíbia, se parte da família materna dele havia permanecido nas imediações da fronteira. Para captar melhor o que foi esse momento, transcrevo abaixo trecho de meu diário de campo daquele dia:

(...) Júlio falou sobre Windhoek e como gostou de ter passado um período da vida por lá, onde estudou. Perguntei onde ele já havia morado. Disse que nasceu no "mato", em Angola, bem próximo à fronteira. Cresceu na aldeia, era o mais velho dos 7 irmãos que haveriam de vir e viver. Em 1987, com 8 anos, havia passado pelo etanda, ritual de iniciação masculino, então já realizava algumas das tarefas destinadas aos homens, como pastorear o gado.

Estávamos conversando em inglês, ele parou e disse em um português arranhado que no "mato" era "trabalho mêmo!", cortar lenha, triturar arroz. Pausou a convers a com um silêncio abrupto, muito incomum em seu temperamento extrovertido. Franziu o semblante e continuou:

- Então fui para a Zâmbia. 
-Zâmbia?-perguntei.

-Sim, era de noite, utalala [tempos de frio]. A UNITA veio de caminhão e colocou todos os garotos maiores lá dentro. Fomos para a Zâmbia.

-Eos mais velhos?

- Não podiam fazer nada, ou levavam as mães também.

Ficamos em silêncio.

-O que vocês faziam?

- Acordávamos antes do sol, carregávamos as coisas, era pesado, aprendíamos a usar as armas, - gesticulando e mostrando os movimentos de preparar um fuzil - buscava comida no mato, era isso. Depois de treinar na Zâmbia fomos no Cuando-Cubango [província no sudeste de Angola, cuja fronteira leste é a Zâmbia e a sulé a Namíbia], e depois por ali na Namíbia.

-Ea sua mãe??

- A mãe ficou à minha procura, a gente não sabia um do outro. Como eu era um dos mais jovens e tinha outros garotos, decidiram me deixar de volta, perto da aldeia, em uma igreja. Os primos eram mais velhos e ficaram. Logo a mãe soube onde eu estava e então fomos todos para Windhoek. Ela não queria mais ficar na aldeia. Mas a guerra logo depois acabou um pouco.

Não consegui perguntar mais nada e logo chegou uma amiga dele. Mudamos de assunto.

Em um primeiro momento, o que mais chamou minha atenção foi o fato de Júlio ter sido uma criança-soldado. Pensei que "não combinava" com seu "bom humor". O que ele teria passado? Como viveu com esse "peso"? Eu não tinha recursos individuais para continuar aquela conversa, pois a perspectiva que tinha construída sobre "crianças-soldado" era fundamentada em ideias de vitimização, sofrimento, trauma.

Não existem dados oficiais, porém sabe-se que tanto a UNITA quanto as tropas do governo (FAPLA, que foram renomeadas para Forças Armadas Angolanas em 1991), utilizaram-se de crianças e adolescentes que raptavam para compor suas frontes, embora as estimativas em relação à UNITA sejam sempre superiores. Há levantamentos gerais, realizados por relatórios de instituições humanitárias, como o Child Soldiers International, que se referem sempre a períodos de tempo. Por exemplo, Honwana (2006) traz uma estimativa, produzida a partir de relatórios institucionais, de que em 1997-ano regido por aparente acordo de paz-havia entre 8.500 e 10 mil menores de 18 anos envolvidos em projetos de desmobilização.

No dia seguinte, tentei retomar a conversa com Júlio, comentando que foi bom ele ter sido levado de volta para os arredores da aldeia, não ter permanecido na guerra e ter ido para Windhoek estudar. Fui surpreendida por 
sua resposta, esta que rapidamente me reposicionou em seu campo de experiências no mundo:

Eu preferia ter ficado no exército [da UNITA]. Assim hoje teria uma profissão, um emprego, poderia me casar e ter meus filhos. Um dos meus primos que ficou hoje está na polícia [de Angola]. Outro é militar reformado. E para mim, o que adiantou estudar? Estudei, fui ativista [em um organismo internacional de prevenção à Aids, em Windhoek], até viajei para a Nigéria, mas e depois? Hoje eu sou um oshiveli [o filho mais velho, que tem obrigações sociais de ser o provedor], um cara velho de 31 anos que não é um homem ainda. Sem emprego, sem filhos, 0 que fazer aqui?

Insisti e mencionei a iminência de morte naquela situação de guerra, mas ]úlio outra vez ponderou, pois "morrer no exército, morrer por não conseguir viver, qual seria a diferença?".

Foi um exercício extremamente difícil ouvir este trecho de sua história de vida de sem estabelecer pontes com meu próprio filho, que tinha oito anos à época, a mesma idade que Júlio quando fora raptado. Imaginava o que seria um grupo invadindo minha casa e levando-o para ser soldado. Criava a imagem de Heloísa mais jovem observando a cena de seu filho, o oshiveli, sendo levado do kimbo.

Nesse sentido, parto de um trabalho que foi fundamental para localizar a situação de Júlio. A antropóloga Alcinda Honwana, concomitante à sua formação e atuação acadêmica, coordenou um projeto das Nações Unidas voltado para o desenvolvimento de uma agenda de pesquisas sobre crianças em conflitos armados (Honwana, 2006).

Ao acompanhar e descrever casos de crianças-soldado, a autora escrutina diferentes trajetórias de meninos e meninas. Observa que se tratam de pessoas que, de alguma forma, são vítimas das contingências, mas que em cada atuação existem nuances que apresentam a possibilidade de agência dessas crianças, modeladas pelos acontecimentos e circunstâncias (Honwana, 2006: 4).

Outra questão destacada pela autora é a menor visibilidade sobre as crianças-soldado do sexo feminino e das mulheres raptadas por tropas em guerrilhas. Durante a pesquisa, Honwana (2006) teve mais dificuldades metodológicas para realizar a proximações com estas mulheres e meninas porque estas não eram autorizadas a interagir em díades com agentes humanitários ou pesquisadores. A interação da pesquisadora com estas mulheres foi sempre em grupos. Mesmo com o fim dos conflitos, uma das maiores dificuldades de programas de desmobilização voltados às mulheres é que muitas delas tiveram filhos e constituíram família, de forma forçada ou não, com combatentes. As atividades femininas nos campos eram similares às dos meninos-soldado: carregar mate- 
riais, realizar tarefas de organização, busca e confecção de alimentos. Além disso, algumas meninas e mulheres eram empregadas como "esposas" ou escravas sexuais nos campos militares.

Uma das mulheres que entrevistei, Cristine, nascida em 1985, chegou a ser raptada junto da mãe e das irmãs. Para sair da região em um período em que os conflitos recrudesceram, sua mãe, de origem kwanyama, com muitos parentes nascidos em território namibiano, saiu com as filhas para buscar refúgio na $\mathrm{Na-}$ míbia, mas antes de chegar foram interceptadas pelas tropas da UNITA:

É, me lembro um pouco, lembro um pouco no Huambo quando passou muita guerra, lembro um pouco. Morava mesmo lá, só que aquela época eu era criança, mas lembro só poucas coisas. Só me lembro de uma vez, eu com a minha mãe, tivemos a refugiar, porque passamos assim, tavam pra vir desses lados, pra vir da Namíbia, família da mãe da Namíbia, aquilo depois raptaram a minha mãe e nós [entrevistada e irmãs]. Ficou um tempo nos matos, Ihes raptaram, a UNITA levou a minh a mãe, ficou um tempo. Depois mais tarde um nosso tio, nos raptou mais nós e a minha mãe ficou o tio nos encontrou e nos raptou e nos levou e a nossa mãe ficou [silêncio]. Ficou lá a sofrer sozinha, depois apareceu mais tarde, mas passou mais de 4 anos [silêncio]. Às vezes quando tentamos contar qualquer coisa, começam as lágrimas... Depois disso a minha mãe apareceu, levou minha família, foi à procura dela, ao ver pra onde está a minha mãe, depois foram à busca dela, a ver onde está minha mãe. Foram à busca dela e ela veio, trouxeram, e ela ficou aqui [no Cunene] um tempo (Cristine, 25 anos, entrevistada em 19 de julho de 2010).

Após o tio ter levado Cristine e as irmãs do campo militar, em uma provável operação de risco, foram posteriormente para Luanda, onde ficaram sob cuidados dos avós paternos. Cristine não falou nada a mais sobre o que lhes ocorrera no campo militar "E o tio nos encontrou e nos raptou e nos levou e a nossa mãe ficou. [silêncio] Ficou lá a sofrer sozinha. Às vezes quando tentamos contar qualquer coisa, começam as lágrimas". A partir das poucas palavras de Cristine é difícil não imaginar uma condição de vítima que ela, as irmãs e, principalmente, a mãe atravessaram. O reencontro da família apenas foi possível pelas ações da rede de apoio familiar, embora não tenha obtido sucesso total na primeira busca. Além do silêncio que ronda o assunto, não foi possível, naquele único encontro com Cristine, vislumbrar como tal evento crítico se desdobrou ao longo do tempo em suas vidas, exceto pelo fato da jovem e suas irmãs terem migrado para Luanda, onde obtiveram suporte afetivo e material dos avós.

Honwana (2006) também alerta para o uso que agências humanitárias fazem sobre os sentidos de "criança-soldado", sempre a partir de concepções 
de infância e juventude genéricas. Outro aspecto central de seu estudo são as consequências de tais concepções, que modelam, por parte destas instituições, geralmente organizações não-governamentais, associadas ou não a programas governamentais ou de agências de cooperação internacional. É assim que programas de reintegração e reabilitação muitas vezes operam, em um sentido de "reparação" que se propõe a trabalhar com perspectivas de indivíduo que não são compartilhadas por quem foi "criança-soldado".

Enquanto Honwana (2006) aponta esse desacordo, destaca também a centralidade que rituais de purificação e cura têm no retorno dessas crianças e adolescentes às suas comunidades de origem, como parte do processo de reintegração social. No caso de Cristine, das irmãs e da mãe, embora não tenham sido mencionados pela entrevistada quaisquer ritos de purificação, observa-se a centralidade da família para o retorno e a reinserção das raptadas. Essa mudança de perspectiva deve ser acompanha por ações no sentido de ampliar o combate à pobreza, reestruturar cidades, criar programas de incentivo ao treinamento vocacional e oportunidades de trabalho e emprego; enfim, um largo e complexo investimento capaz de responder às demandas políticas e econômicas geradas pelos anos de colonialismo e guerras.

Vitimização... Foi assim que recebi inicialmente a história do Júlio criança-soldado. Volto à sua história para mais algumas ponderações. Tardei a compreender que os impactos negativos da guerra em sua vida não estavam estritamente relacionados ao fato dele ter sido criança-soldado. Para ele, ser um homem sem emprego era muito preocupante, pois a renda fundamentaria seu papel na sociedade. A partir do acesso a renda e ao trabalho, Júlio poderia ser oshiveli, o filho e irmão mais-velho, casar-se e ter filhos, completando seu sentido social. Com mais de 30 anos, sem emprego, sem renda e sem querer mais viver no kimbo como agricultor, Júlio reclamava sua própria condição masculina. Homem que ele começou a ser desde o ritual de iniciação, aos 8 anos pouco antes de ter sido raptado pela UNITA, e que se completaria com a paternidade e o papel de provedor. Seu processo de constituição social masculina foi interrompido, não exclusivamente por ter sido criança-soldado, mas por não ter conseguido colocação nas estruturas sociais que foram esfaceladas pelos anos de guerras.

Da infância em um kimbo kwanyama do lado angolano, pouco restou para sua família. O retorno de Júlio nos anos 1990 foi o ponto de partida para a decisão de Heloísa, sua mãe, emigrar para a capital da Namíbia com os filhos. O elo era Dona Belinda, a administradora do bar-pensão em que Júlio e Heloísa trabalhavam. Heloísa havia trabalhado como doméstica para Dona Belinda, uma angolana branca de ascendência portuguesa, poucos anos antes da Independência, e continuou a Ihe prestar serviços esporadicamente. Com a Independência de Angola, Dona Belinda, como tantos ex-colonos de ascendência portuguesa que 
temiam retaliações, emigrou para a Namíbia. Retornou a Angola em 2003, pois percebeu em Santa Clara uma boa oportunidade para gerenciar um bar-pensão.

Júlio havia frequentado alguns anos da escola primária em uma missão católica próxima a seu kimbo de origem, onde fora alfabetizado em kwanyama. $\mathrm{Na}$ época, o padre da missão sugeriu à Heloísa que buscasse documentos para os filhos como se tivessem nascido do lado namibiano, pois assim teriam mais chances de mobilidade. Em Windhoek, deu continuidade ao processo de escolarização básico, onde aprendeu inglês e africâner. Os meados dos anos 1990 na Namíbia foram marcados por políticas de prevenção e contenção da epidemia de HIV/AIDS voltados para jovens. As campanhas eram realizadas em diversas frentes, uma delas em escolas. Júlio, por sua habilidade comunicativa e carisma, destacou-se como peer educator entre jovens estudantes. Viajou para diversas províncias da $\mathrm{Na}-$ míbia, viajou para a Nigéria. Entretanto, a remuneração oferecida era insuficiente para sua colaboração familiar como oshiveli, filho e irmão mais-velho.

Em 2001, um dos irmãos de Heloísa faleceu. Ele havia sido conselheiro da aldeia em que vivia, do lado namibiano, próximo à fronteira. Ela foi chamada para participar da administração rotineira da produção agrícola e Júlio precisou acompanhá-la. A partir de 2003, com o retorno de Dona Belinda para Santa Clara, Heloísa e Júlio viviam entre o kimbo, na época de plantar e colher massango, e o bar-pensão. Apenas eventualmente recebiam dinheiro, Dona Belinda dizia que já lhes dava muito com "casa e comida".

A trajetória de Júlio apresenta mais os impactos indiretos da guerra em sua vida do que o próprio fato de ter sido raptado pela UNITA. O deslocamento de seu kimbo para a guerra, e da guerra a Windhoek, em uma relação sempre marcada pela exploração do trabalho (seu e de Heloísa) gerou inconstâncias que tornaram difícil sua adaptação em um mundo que não ofereceu grandes possibilidades de inserção via trabalho. A Independência da Namíbia em 1990 não foi o suficiente para apagar os anos do sistema de apartheid sul-africano. Windhoek era uma cidade que refletia consequências do regime que continua, até hoje, a excluir negros e mestiços. Mesmo com a escolaridade básica, não há muitas oportunidades de trabalho para jovens negros. No kimbo, Júlio não encontra mais identificação com o trabalho agropastoril. Na fronteira, Júlio não é mais angolano. Queria trabalhar como marceneiro ou eletricista, mas suas memórias de guerra - as indiretas - os necessários deslocamentos, as poucas oportunidades de subsistência abertas fizeram dele, aos 31 anos, um sobrante com parte de si socialmente não reconhecida. Sua trajetória não coube nos princípios da reconstrução nacional angolana.

Apesar disso, Júlio manipulava sua "invisível" condição a seu favor. Mantinha em segredo a documentação de natural de ambos os países, circulando entre as intermitências de onde pudessem surgir novas oportunidades. E embora lhe fos- 
se difícil arranjar um casamento, o que o entristecia, mantinha algumas namoradas que, por conhecerem sua condição precária de trabalho, não Ihe exigiam suporte financeiro e material.

\section{"A GUERRA MESMO"}

A trajetória de Eneida foi de maior sorte. Ela nasceu em 1967, "do outro lado do rio Cunene", na direção de Lubango, capital de Húla, em um kimbo de origem nyaneca-humbe. Um de seus irmãos foi para as tropas do governo e morreu em princípios da década de 1980. Para ela, o que a "salvou" foi o abrigo na missão católica irlandesa que abrigava crianças e famílias da região. Lá estudou e se profissionalizou como técnica de enfermagem obstétrica. As freiras tinham acordos com as SADF para que a missão não fosse atacada. Conseguiam até mesmo um feito considerado impraticável em certas épocas, que era transitar de carro, pois identificavam-se com uma bandeira branca. Nas proximidades da missão, violações e mortes repentinas não aconteciam com tanta frequência.

Em 1991, Eneida se mudou para Ondjiva e lá teve seus 3 filhos. Durante as noites da guerra disse que dormia "de um olho só", porque pensava no que deveria fazer se fosse atacada. Conviveu com rumores na vizinhança de que uma emboscada estaria prevista para certas noites. Contou que, no desespero, mulheres pegavam rapidamente as coisas para fugir, confundindo cachorros e sacolas com crianças. Para ela, sua maior dor era todas as noites de conflito se preparar para escolher um dos filhos que precisaria deixar em caso de ataque.

Os rumores em Ondjiva não eram notícias alarmistas. Os carros não circulavam nas ruas e quando o faziam, eram camuflados por folhas. Quando os aviões se aproximavam, as pessoas que por acaso estivessem nas ruas paravam imóveis, escondiam os dentes, fechavam os olhos e as mãos, para que o sol não refletisse as partes de destaque dos corpos que pudessem denunciá-los. Após as 18 horas tudo deveria ficar apagado: nem candeeiro, nem carvão para a comida, nada deveria ser aceso. Não havia construções além de casas de adobe. Mulheres eram raptadas, as crianças não tinham como ir à escola, que mal existiam. Eneida diz que teve sorte, que hoje tem uma profissão e que nada aconteceu a seus filhos.

Em seu caso, a presença de uma "ajuda humanitária", sob a forma de uma missão religiosa, foi transformadora, pois ofereceu-lhe uma formação profissional. Sobre a guerra, Eneida sempre fazia referências às consequências dos processos da guerra, do que não se capta sob um olhar rápido, desde sua fala presente no dia que a conheci, como na constante repetição em que contava e recontava o que faria se precisasse escolher um dos filhos em caso de fuga.

Uma das amigas e colegas de trabalho de Eneida, Fátima, em contraste, por 
pouco não foi penalizada por sua profissão. Nascida nos arredores de Santa Clara, viveu um período em um campo de refugiados na Namíbia, mas retornara ao Cunene em 1996. Explicou que ali, a "guerra mesmo", ela viu apenas em 2002, como segue no trecho de diário de campo. Neste dia, relatei as palavras de Fátima em primeira pessoa, tentando acompanhar o que me havia dito na hora anterior, ao relatar-me sua história:

Nesse dia ouvi os soldados se aproximarem. Alguém Ihes disse: "Tem enfermeira naquela casa!". Fugi. Corri, corri até alcançar o hospital que estava na fronteira. O Marido colocou o mais velho deitado no capim e segurou o caçuli [mais novo]. A menina maior estava aos seus 14 anos, o pai lhe mandou ficar deitada embaixo do lençol encol hida para que não se apercebessem dela ou de seu tamanho de moça. Os soldados entraram e perguntaram ao marido sobre mim, "a enfermeira que ali morava". Ele disse que eu havia morrido há um mês e que lhe deixei apenas o bebê. Os soldados queriam algo mais e avisaram que só havia uma chance de não matá-los: se na casa tivesse dinheiro para lhes entregar. Àquela época era difícil ter dinheiro em casa, era trabalho sem receber, percebes? Mas Deus estava conosco mesmo. Eu guardava um dinheirinho que recebi na kixikila uns dias antes. Iria para Oshakati [na Namíbia] ver minha mãe e estava com aquele dinheiro. Eram 700 randis [aproximadamente 100 dólares].

O Marido sabia desse dinheiro, que eu deixava em uma latinh a de mantimentos para que, se uma tropa invadisse minha casa, não encontrasse. Ele entregou o dinheiro aos soldados. Eles pegaram o dinheiro e deixaram um papel. Nesse papel, que está guardado a té hoje, está escrito que eles estiveram ali. Assim, o próximo grupo de soldados que chegasse não deveria nos fazer mal. Eassim foi. Mais um grupo apareceu, o papel foi mostrado e não nos aborreceu. Depois teve outro grupo, fizemos o mesmo, eles se foram sem aborrecer. Acredito que eram 7 grupos $d a$ UNITA aqui em Santa Clara e 3 nos visitaram. Viam o documento e iam embora. Levaram todos os sapatos do Marido e também as roupas que eu usava. Mas isso conseguimos depois, já a vida... O mais triste foi a minha corrida e a espera. Pensava: "Eu volto, mas será que ainda tenho família?". Fiquei ali escondida naquele hospital abandonado, não tinha mais ninguém. Esperei o cessar-fogo e retornei para casa. Parecia que mais perto de casa estava, mais havia a destruição. Ouvi vozes a agonizar. Uma delas era um vizinho, com um tiro na barriga. Na pequenina casa de adobe de uma vizinha... [silêncio] Éramos amigas, o corpo dela estava todo ensanguentado, jogado no chão, sem vida. Queria encontrar minha casa, parecia tão longe, meu coração perguntava se meus filhos estariam a viver. Eles estavam, todos! A menina não respirou na presença da tropa, encolhida. Se fosse encontrada, penso que teriam todos levado tiros... O menino esteve à beira dos tiros no capim, mas logo que percebeu os ruídos, correu para casa. Foi muito 
difícil, ver aquelas luzes dos tiros rasgando a terra, tanta destruição. Quem sobreviveu, um ajudava o outro como podia e mais do que podia. Essa vez foi a guerra mesmo que vi aqui.

Fátima contou essa passagem de sua vida em uma tarde amena em Santa Clara, em um dia em que ela atuou como intérprete de uma entrevista que realizei com uma jovem que falava apenas kwanyama, no posto de saúde em Santa Clara. A entrevistada era órfã de guerra e havia sido criada pela avó, com quem precisava sempre fugir de um lado ao outro entre os matos nas épocas de ataques. Logo que a menina foi para casa, Fátima parece ter aberto suas memórias e relatou detalhadamente a "guerra mesmo" que vivenciou.

A "guerra mesmo" é uma referência da experiência em si, mas que é revelada além do evento em si, em silêncios profundos ou condensada nos episódios mais marcantes que foram vividos. Os deslocamentos de Fátima foram moldados pelas guerras, mas ela destaca a literalidade do que viu nesse episódio de 2002. Em certos casos, é como se apenas os eventos críticos fossem imediatamente associados às guerras. De forma similar que a interlocutora a seguir indica que viu "uma guerra só".

\section{UM OUTRO “NOME DA TRISTEZA"}

Tão logo conheci Valentina, ela explicou-me que seu verdadeiro nome, em sua língua materna, significava "aquela que traz rancor": "Quando me nasceram, o pai deu esse nome da tristeza. Eu fiz a família romper, sou a tristeza e o rancor da mãe com o pai". O rancor que carregava no nome dado pelo pai referia-se a uma tragédia familiar que ocorrera em 1987, enquanto a mãe ainda gestava Valentina. O irmão mais velho da moça estudava em Cuba e retornou nas férias para visitar a família. O pai, que estava na Namíbia trabalhando, decidiu que ele deveria permanecer e acompanhá-lo no trabalho, afirmando que em Cuba o rapaz estaria perdendo tempo sem fazer nada. A mãe insistiu que o rapaz continuasse a estudar em Cuba. Em um desfecho trágico, em uma manhã, o rapaz apareceu em sua cama, esfaqueado e morto. As acusações recaíram sobre o pai como mandante do crime. A família da mãe se reuniu e concluiu que o assassino do rapaz era o pai. Abrigaram então a mulher gestante e seus outros cinco filhos. O pai, que sempre negou o assassinato, e vivia nos arredores, em outro kimbo com suas outras esposas, voltou após o nascimento de Valentina para lhe dar um nome, em ritual específico, e ali a bebê ganhou "esse nome do rancor".

"Eu fiz a família romper", o nome da tristeza representava não a si própria, mas ao conturbado período que a família atravessou na época que Valentina nasceu. A mãe não queria que o filho mais velho corresse o risco de ser captura- 
do por alguma tropa, um medo plausível de quem via rotineiramente crianças e adolescentes sendo levados de seus kimbos para serem soldados. Em Cuba, o rapaz estaria mais resguardado, e, além disso, teria mais garantias quanto à formação escolar. A perspectiva do pai, de que a família precisava de outra fonte de renda, era outra. Um rapaz, principalmente o mais velho, tem obrigação de buscar outras formas de sobrevivência - e o contexto de guerra tornava difícil o sustento familiar.

Durante a guerra, as escolas de áreas rurais e mesmo em capitais de províncias mais afetadas foram destruídas. A própria Valentina, ao atingir a idade escolar, foi viver com a irmã da mãe em um povoado onde ainda havia escola. A subsistência pela agricultura e criação pastoril, já dificultada pelas condições climáticas do sul de Angola, tornou-se praticamente impossível. Os convênios de saúde e de educação entre o governo oficial de Angola e Cuba eram uma saída que alguns pais encontravam para proteger ao menos alguns de seus filhos homens.

A dificuldade de se manter, a possibilidade de proteger um filho da guerra, o conflito entre diferentes posições, o assassinato do filho mais velho; a história resultou em acusações contra uma das partes sobre a morte do rapaz. O pai, o principal suspeito, condensou todas as representações de dor daquele período na criança que estava sendo gestada e nasceu: como uma dádiva burlesca, uma filha mulher, "aquela que trouxe o desgosto". "Sou a tristeza e o rancor da mãe com o pai".

Na trajetória da jovem, seus movimentos migratórios estiveram associados indiretamente ao recrudescimento dos conflitos na região da fronteira. Para manter as crianças e mais jovens na escola, a família os encaminhava a cada uma das irmãs-da-mãe que morassem em uma área menos destruída que contasse com uma escola. Foi assim que Valentina viveu entre as casas de tias, entre Angola e Namíbia. No entanto, ao ser indagada sobre a época das guerras, ela diz que "só viu mesmo uma guerra só" e narra um episódio, o mesmo que Fátima relatara, como passageiro, de um ataque das tropas das forças opositoras ao governo ao povoado em que vivia:

Já era um pouco criança, eu só me lembro a guerra que se passou aqui no Namacunde em 2002, a única guerra foi que eu vi só. Eu só escutei uma vizinha, nos bateu a porta, disse: "Acordem, a UNITA está daquele lado, todo mundo tá a fugir!". Nós estávamos a correr de tiro mesmo. Ao lado da nossa casa tinha uma mais-velha cega, uma vizinha, uma mãe de uma nossa vizinha... Então, não tinha como levar aquela mais-velha, deixamos mesmo aíe fugimos. Fomos parar lá naqueles matos, e a UNITA ficou aqui no Namacunde, desfez, queimou as casas, estragou as coisas, fugiram e assassinaram, assim cortaram as cabeças. $A$ mais-velha encontramos, quando chegamos encontramos, cortou a cabeça. Fugi- 
mos, andamos, inflamamos até os pés de tanto andar. Eles [a tropa do MPLA, do governo] vieram acudir aqui, porque eles estavam aqui a desfazer, queimaram o comando da polícia. E vinham com bombas, vinham com muita coisa. E depois com a tropa, depois de ver que a UNITA foi distante, eles também acompanharam, mataram alguns muitos da UNITA, eles começaram a recolher o povo, Ihe apanhava ali nos matos e Ihes trouxeram. Chegamos aqui e encontramos muitos matados, mortos, vários só cortados mesmo assim com as facas, uns queimaram dentro de casa, às vezes dentro de casa só a tirava assim o fogo. A pessoa tá dentro, queimou, a pessoa morria aí, e a guerra teve muitas, de resto não vi nada, encontrei, quando aqui no Cunene tinha de guerra, nós tínhamos fugido pra Castanheira, do lado do Lubango, estávamos lá com a minha tia. Ea guerra veio encontrar aqui, mas felizmente só deram tiro numa tia minha que vivia aqui assim, mas ela não morreu, e eu, e eu e essa mais-velha que encontramos, que lhe contei já era nossa vizinha. A velha, ela era cega, não enxergava. Aqui não podia passar nessa mata, não se passava, tinha UNITA. Foi a única guerra que eu vi. (Valentina, 23 anos, entrevistada em julho de 2010)

A "única guerra" que Valentina viu foi a mesma que atirou em uma de suas tias, dispersou a família por diferentes lugares, decapitou a vizinha cega e destruiu o povoado em que vivia quando tinha 14 anos de idade.

Esse detalhamento do que foi o retorno ao povoado após o ataque constrói uma cena de destruição que traz aspectos similares àqueles do visitante que chega ao centro de Ondjiva e observa o monumento de escombros.

Entretanto, essa descrição, feita no contexto de uma entrevista gravada, foi a resposta a uma pergunta sobre como era a época da guerra e não era exatamente a "única guerra" na trajetória de vida narrada por Valentina. Tão ou mais comoventes que os episódios narrados - o do assassinato do irmão ou do ataque ao povoado - são as maneiras que a jovem tem buscado para reabitar este universo destruído não só pela violência brutal de um estado de guerra, mas pela violência banal de "uma lembrança sempre a sangrar", de "coisas que não se sabia que eram sabidas", como na poética do romancista angolano Ondjaki (2013). Como viver a partir disso?

Em 2005, aos 18 anos, Valentina casou-se com Manoel, sob aprovação familiar e festejos tradicionais: apresentação do rapaz, análise familiar sobre o comportamento do pretendente, a consolidação de alianças familiares pela festa de alembamento. Mudou-se para a casa da família do marido. Após alguns meses de casamento, Valentina incomodou-se porque Manoel começou a beber muito. Mas foi no fato de não ter engravidado que conseguiu um álibi para desfazer o casamento. Inicialmente, foi responsabilizada por não engravidar, " $E$ aí depois as irmãs [do marido] começou a me insultar, 'que você não faz filho, não 
sei que'..... Em seguida, Valentina conseguiu ver nisso a possibilidade de desvencilhar-se do casamento que não Ihe agradava: "E eu tinha mesmo que sair, tinha que lhe deixar, porque eu não vou escutar toda hora a me insultar nas irmãs, nas primas, que 'a mulher que você arranjou não faz filho'. Apenas o uso que o primeiro marido fazia da bebida não seria o suficiente para romper a aliança, mas as ofensas provocadas pelas mulheres da família do marido pela ausência de gravidez foram legítimas para que a família de origem da jovem a chamasse de volta e desfizesse o casamento. Esse novo arranjo foi possível porque após o fim das guerras (2002), a família de Valentina pode se reunir de novo. Uma decisão individual dela poderia resultar em um duplo rompimento: com sua família de origem e com a família do primeiro marido.

De volta à casa da irmã da mãe, quis um novo marido. Logo casou-se outra vez e engravidou. Sua vida foi retomada na casa do novo marido, Francisco, que era vizinho, e a jovem ganhou um novo núcleo familiar, composto pelo marido, o sobrinho deste, Valentina (que estava grávida) e sua sobrinha. 0 novo casamento Ihe parecia bom até que outra situação delicada se colocou em vista.

Em uma fronteira cuja alta prevalência para HIV/Aids se expressa entre amigas e conhecidas doentes e já falecidas em decorrência de doenças oportunistas, e em um contexto que os homens quase sempre mantêm múltiplas parceiras concomitantes, Valentina buscava alertar o marido para a prevenção, para o uso do preservativo. Sabia que uma das namoradas de Francisco era viúva de um rapaz que havia morrido em consequência da Aids e logo se incomodou com uma permanente ferida que o marido tinha em seu pênis. As últimas vezes que havia realizado o teste para detectar o HIV haviam sido durante a gestação da filha e após seu nascimento, o que é um procedimento padrão. Evitou repetir o teste depois de desconfiar do machucado no marido, pois, "se vais fazer o teste sozinha, sem o marido lhe pedir, e ele sabe, ele vai a pensar que tens outro". Por isso, Valentina repetiu o teste na oportunidade aberta por uma pesquisa de saúde conduzida com mulheres na região, desvinculada aos locais comuns de testagem.

Em nossa conversa, fazia apenas dois meses que Valentina soubera que era soropositiva. Ao receber o resultado, a jovem foi instruída a conversar com o marido, então seu único parceiro sexual. Antes, ela contou para a tia, que reforçou a necessidade da conversa com Francisco, pois "foi o marido que me colocou nessa condição". Horas depois, quando o marido chegou à casa, encontrou Valentina aos prantos, como jamais havia visto. Ela Ihe contou que havia testado positivo para HIV. Francisco respondeu agressivamente, dizendo que ela trouxera a doença para ele, que se achava saudável. Ele se recusou a fazer o teste e saiu de casa.

Valentina, com a filha, a sobrinha e o sobrinho do marido, esperou por ele 
durante um mês, enquanto foi possível permanecer com recursos mínimos para a alimentação. Procurou a mediação de um dos irmãos de Francisco, que o encontrou em uma nova casa na zona urbana da capital da província do Cunene, vivendo com outra mulher, que estava grávida. O cunhado achou que o mínimo a ser feito era que Francisco desse dinheiro a Valentina, afinal, ela estava responsável, além da filha, pelo sobrinho dele. Diante da intervenção do irmão, Francisco disse a ele que saiu de casa porque viu Valentina chorando e achou que ela iria se matar. Depois, o cunhado voltou a falar com o irmão. Francisco disse para que fosse encontra-lo em sua casa, que ele já "estaria a vir". Dois dias se passariam e ele não apareceu. O cunhado deu um pouco de dinheiro a Valentina ("que comprei um bocado de fuba e o material escolar"). Ao seguir sem novas notícias do marido, por fim, a família dela, na figura da tia, "tomou conta da situação", ao menos por um período, abrigando Valentina e as crianças. Entretanto, ela não poderia permanecer muito tempo na casa da tia: "Pedir na tia já não sei quanto tempo posso (...). O meu marido Ihe faltou responsabilidade".

Assim, uma das alternativas vislumbradas por Valentina era esperar pelo retorno do marido e, de forma paralela, criar novas estratégias para gerar renda. Ao conversarmos pela última vez, a jovem disse que estava sendo cortejada por um colega de escola, que a levava à Namíbia para comprar roupas para sua revenda, entregava-Ihe dinheiro para comprar mantimentos e o material escolar. Essa atenção representava, naquele contexto, uma aproximação com interesses de estabelecer uma relação afetivo-sexual, ou, como ela descrevia, era uma "amizade interessada".

O dilema de Valentina consistia em saber que não poderia continuar com as crianças na casa da tia sem contribuir efetivamente com recursos materiais. Tampouco achava correto completar o ciclo dadivoso do relacionamento iniciado por seu colega de escola iniciara porque era soropositiva e, mesmo que propusesse o uso do preservativo, ele poderia negar. Se contasse a ele que era soropositiva, perderia aquele que era seu suporte afetivo e financeiro. Enquanto isso, continuaria à espera do marido.

Valentina, essa que "tem o nome da tristeza por ser o rancor da mãe com o pai", buscava sempre a conciliação, o cumprimento das normas e das decisões dos mais velhos. Ela dizia estar "a esperar de tudo que aparecer, já que estava a viver", por isso pensava que precisava "receber o que a vida traz". Essa maneira de lidar com os acontecimentos não significava completa resignação e silêncio, mas uma conformação subjetiva de quem conhece bem aquele universo social ao ponto de reinventar-se para criar alternativas diante de tantas adversidades. Sua história ecoa o ato de testemunhar, que, como sugerido por Das (2007), não se expressa como "memória traumática do passado que chega ao presente", mas como o conhecimento venenoso obtido pelo sofrimento. A 
transformação desse envenenado conhecimento é a possibilidade de retornar à vida, em que perdas e rupturas são vivenciadas, mas em cujos interstícios também são criados outros significados para estar no mundo (Das, 2007: 76). Valentina vai ao ordinário do cotidiano e busca elementos para resistir, dentro de seu universo cultural.

\section{EM BUSCA DE EMPREGO E/OU RENDA: A EXPERIÊNCIA DO PÓS-GUERRA}

Amália, nascida em 1988, identificava na guerra o principal motivo de esgarçamento das relações familiares, o que tornara a vida mais difícil. Sua mãe, de origem kwanyama, permaneceu no Cunene durante o período de guerras, mas preferiu deixar a filha com a irmã, que vivia em outra província. Na casa da tia, a prioridade era o trabalho doméstico e por isso a jovem deixou de frequentar a escola com assiduidade. Terminada a guerra, a mãe pôde visitá-la e ao saber desta situação, trouxera a filha para sua casa no Cunene. Amália explicou que os tempos atuais estavam bem melhores, pois:

Agora já há pessoas que conseguem estudar, há pessoas que conseguem estudar normalmente... Naquele tempo, a pessoa não tinha como estudar... e também não tinha como... como é que eu posso dizer... não tinha como, como... conseguir emprego, conseguir emprego devido a essa guerra. Agora, a guerra cessou, a pessoa sente-se livre, paz, de andar, procurar emprego. E também não só... a minha família, digo que também, porque já consegue se procurar, agora já consegue se procurar. Antigamente, já não... Ficavam isolados, porque a maioria que vivia no Huambo, no Lubango tinha sempre medo de vir aqui procurar a família, porque eles pensam que a qualquer momento vão atacar, vai haver guerra, esse é o medo que eles sentiam... (Amália, 22 anos, entrevistada em julho de 2010).

De todas as 25 mulheres que entrevistei formalmente, Amália foi uma das poucas que tinha um emprego formal e, talvez por isso, dizia que era fácil conseguir trabalho na região, enquanto a maior parte das entrevistadas fazia uma distinção entre "conseguir dinheiro, porque ali o dinheiro aparece e se faz negócios" e "conseguir trabalho/emprego". O emprego da moça era no comércio formal, no qual recebia um salário de 25 mil kwanzas (cerca de 250 dólares). Isto fazia dela a principal provedora da família, que incluía ela, a mãe, os irmãos, o filho e o marido:

Eu tô a suportar... eu é que sou... digo, eu é que sou a responsável daquela casa, eu é que cuido dos meus irmãos, praticamente, a escola dos meus irmãos... a minha mãe já não tá com meu pai... ela também precisa... eu quando recebo o meu 
salário, eu tenho que saber dividir. Tenho que tirar dinheiro pra comprar roupa pras crianças, tenho que pagar... às vezes, os cadernos, o resto, e a mãe precisa de dinheiro, tenho que dar dinheiro, porque ela tá a fazer uma obra ali no Xangongo, eu divido sempre. Assim, quando o mês acaba, eu tiro 10 mil, dou na mãe... o resto, os 15 mil, eu consigo economizar... Epa, assim, [o salário] não chega assim tão lá bem. Mas eu fiz algo... peguei meu dinheiro, peguei um dinheiro, meti lá na gasosa [neste contexto, refrigerante], cerveja em casa, pras pessoas começarem a vender, as crianças começaram a vender, ao menos ajuda na casa, comprar assim, óleo, o resto. Equanto àquele dinheiro, quando vem, a pessoa consegue já fazer qualquer coisa (Amália, 22 anos, entrevistada em 23 de julho de 2010)

Mesmo com seu trabalho formal, a renda obtida não era o suficiente para a família. Sua mãe trabalhava eventualmente e seus recebimentos eram instáveis. O marido, Joca, 25 anos, trabalhava na alfândega com "desenrasca" e ela o considerava "ainda criança", pois "gasta[va] muito fora de casa com a amante". Como saída, Amália pensou na revenda de bebidas em casa, feita pelos irmãos.

Em um período de estafa emocional no relacionamento com Joca (“... eu me sentia muito sozinha... ele vai, fica dois dias fora de casa... fazer nada... ele não conversa comigo, ele lá na rua fica feliz, mas quando chega em casa fica chateado..."), Amália buscou apoio afetivo em um amigo, Rique, que já havia cultivado o hábito de lhe dar presentes e dinheiro. Rique a levava para almoçar em restaurantes e, além disso, "ele sempre tinha música pra cantar pra mim, pegava na viola, cantava sempre música... [risos]". Assim Amália começou a investir em um relacionamento afetivo-sexual com Rique, a quem classificava como "amante". Com seis anos a mais que Joca, Amália dizia que Rique era "adulto já", com um trabalho fixo que possibilitava uma "ajuda" financeira quase equivalente ao seu salário. Dizia que de Joca, o marido, "gostava mesmo" e sobre Rique, "sentia uma atração".

A mãe de Amália sabia de seu relacionamento com Rique e costumava aconselhar a filha a interrompê-lo. Mas o afeto e a "ajuda" de Rique lhes eram essenciais naquele momento.

Ressaltei um dos aspectos afetivo-sexuais na trajetória de Amália para apresentar uma face da complexa estruturação de possibilidades de renda das mulheres de sua geração. Amália estudava para obter melhores trabalhos no futuro, era a principal provedora do agregado familiar, tinha um emprego formal, mas não gerava a renda necessária. Com a revenda de bebidas e a amizade com Rique, ela poderia, como explicou, "sonhar mais longe".

Amália não testemunhou diretamente a guerra, mas a tem como alguém que a vivencia como esse elemento de desestruturação. Com a reunião da família no pós-2002, coube a ela a responsabilidade central da organização material de sua família: a mãe, os irmãos mais jovens e o filho. Sobre Joca, "o marido ain- 
da criança", não era possível ter expectativas. E para reabitar um mundo destruído, era preciso criar novas concessões.

\section{CONSIDERAÇõES FINAIS}

A proposta deste artigo foi apresentar como trajetórias de pessoas que passaram por experiências de guerra trazem em si a história incorporada (Fassin, 2007) da região. Ao percorrer fragmentos dessas narrativas, observa-se que os meios de lidar com as adversidades estão além de perspectivas relacionadas a noções de vitimização que percorrem programas institucionais de pesquisa ou de intervenção. Amália, Valentina, Fátima, Cristine, Júlio, dentre tantos outros, buscam sobreviver de maneira diferente do propalado discurso da "reconstrução nacional". As respostas desses interlocutores às experiências atravessadas apresentam singulares jeitos de reabitar o mundo, a partir de conhecimento obtido através do sofrimento gerado pelo esgarçar das redes sociais e da destituição de espaços públicos de convivência. Ter visto "uma guerra só"; estar "à espera do marido"; receber a ajuda financeira e afetiva de uma "amizade interessada"; trabalhar de modo itinerante e nem sempre remunerado; todas essas são formas que ultrapassam o lugar do trauma e que se adaptam diariamente às possibilidades diante daquele contexto.

Camila A. M. Sampaio é professora do Departamento de Sociologia e Antropologia da Universidade Federal do Maranhão e doutora em Ciências Sociais pela Universidade do Estado do Rio de Janeiro.

\section{REFERÊNCIAS BIBLIOGRÁFICAS}

ANDERSON, Benedict

1998 The Spectre of Comparisons: Nationalism, Southeast Asia, and the World. Londres e Nova York, Verso.

DAS, Veena

1995 Critical Events: An Anthropological Perspective on Contemporary India. Nova Delhi, Oxford University Press

2007 Life and Words: Violence and the Descent into the Ordinary. California, University of California Press. 
DOMINCOS, Nelson A.

2013 Transição pela transação: uma análise da democratização em Angola. Rio de Janeiro, tese de doutorado, Universidade do Estado do Rio de Janeiro.

FASSIN, Didier

2007 When Bodies Remember: Experiences and Politics of Aids in South Africa. Berkeley, The University of California Press.

HODGES, Tony

2002 Angola: do afro-estalinismo ao capitalismo selvagem. Cascais, Princípia.

HONWANA, Alcinda

2006 Child Soldiers in Africa. Ethnography of Political Violence.

Philadelphia, University of Pennsylvania Press.

ONDJAKI

2001 Bom dia camaradas. Luanda, Chá de Caxinde.

2013 Os transparentes. São Paulo, Cia das Letras.

RODRICUES, Cristina U.

2010 "Angola's Southern Border: Entrepreneurship Opportunities and the State in Cunene". The Journal of Modern African Studies, n.48, vol. 3: 461-484.

SAMPAIO, Camila A. M.

2014 Através e apesar da "reconstrução nacional" em Angola:

circunstâncias e arranjos nos limites da vida. Rio de Janeiro, tese de doutorado, Universidade do Estado do Rio de Janeiro.

VICNE, Randolph

1998 "The Moveable Border: The Namibia-Angola Boundary Demarcation". In HAYES, Patricia et al. (orgs.). Namibia under South African Rule: Mobility and Containment, 1915-1946. Oxford, James Currey, pp. 289-304.

WILLIAMS, Christian

2009 Exile History: An Ethnography of the SWAPO Camps and the Namibian Nation. Detroit, tese de doutorado, University of Michigan. 


\section{ABSTRACT}

In this article I will emphasize the presence of the past war as a critical event in the trajectory of some urban residents in Cunene, southern of Angola. It will be described general historical aspects of the region to comprehend the ontext of episodes of violence that marked the territory. After that, it will be analyze how the State itself chooses an unorthodox monument as a symbol of the destruction caused by the war, making itself as an image of State for peace. In the following sections, it will be present trajectories and perceptions of people who experienced the war in different intensities and rework daily ways of being in the world. The act of announcing phrases like "I saw only one episode of war" ; I will be waiting for my my husband"; or receive financial and emotional help from a "interested friendship"; or work on a mobile basis and not always paid ; these are all ways that go beyond the place of trauma and represents the daily adaptation to the possibilities in that context.

Recebido em 1 de dezembro de 2016. Aceito em 2 agosto de 2017.

\section{KEYWORDS}

Angola, War, Postwar, Critical Events, Daily Life 